\title{
PERAN NOTARIS DALAM MEMBERIKAN PEMAHAMAN HUKUM KEPADA MASYARAKAT YANG KURANG MAMPU \\ DALAM MEMAHAMI HUKUM KAITANNYA DALAM PEMBUATAN AKTA-AKTA NOTARIIL DI WILAYAH KEDU SELATAN
}

\author{
Rahmat Solehan
}

Gunarto

\begin{abstract}
ABSTRAK
Tujuan dari penelitian ini adalah untuk mengetahui dan mengkaji pemahaman masyarakat terhadap akta notariil dan fungsinya; peran Notaris dalam memberikan pemahaman hukum kepada masyarakat yang kurang mampu dalam memahami hukum kaitannya dalam pembuatan akta-akta notariil di wilayah Kedu Selatan; serta peran Ikatan Notaris Indonesia (INI) dalam pembinaan terhadap Notaris untuk memberikan pemahaman hukum kepada masyarakat yang kurang mampu dalam memahami hukum kaitannya dengan pembuatan akta notariil.

penelitian ini termasuk dalam jenis penelitian hukum normatif, karena penelitian ini berangkat dari adanya kekosongan norma (rechtsvacuum). Jenis pendekatan yang diterapkan dalam penelitian ini adalah jenis pendekatan perundang-undangan (statute approach). Bahan hukum yang telah dikumpulkan dan disistematisir kemudian dilakukan analisis secara kualitatif.

Hasil dari penelitian ini adalah (1) Pemahaman masyarakat tentang akta notariil dan fungsinya belum memadai, sehingga banyak orang yang menuangkannya di dalam akta Notaris, baik itu yang berbentuk perikatan yang melibatkan pihak lain maupun sekedar untuk menyatakan maksud tertentu agar dijadikan sebagai dokumen legal yang mempunyai kekuatan hukum, dengan harapan untuk mendapatkan kepastian hukum dikemudian hari. Akan tetapi banyak masyarakat ataupun para penegak hukum dan bahkan para Notaris sendiripun masih banyak yang kurang memahami peranan tugas dan tanggung jawab Notaris dalam masyarakat terutama dalam membuat akta autentik; (2) Peran Notaris dalam memberikan pemahaman hukum kepada masyarakat yang kurang mampu dalam memahami hukum kaitannya dalam pembuatan akta-akta notariil dilakukan dengan penyuluhan hukum kepada kliennya, dapat dibagi menjadi 2 (dua) kriteria, yaitu penyuluhan hukum yang diikuti dengan pembuatan akta dan penyuluhan hukum tanpa diikuti dengan pembuatan akta. Penyuluhan hukum yang diikuti dengan pembuatan akta merupakan satu kesatuan yang tidak dapat dipisahkan; serta (3) Tugas Ikatan Notaris Indonesia (INI) dalam pembinaan Notaris tidak lepas dari pada penegakan Etika Notaris, meliputi norma agama, norma hukum, norma kesusilaan, dan norma kesopanan. Norma agama, norma kesusilaan, dan norma kesopanan berhubungan dengan etika. Kode Etik dalam arti materiil adalah norma atau peraturan yang praktis baik tertulis maupun tidak tertulis mengenai etika berkaitan dengan sikap serta pengambilan putusan hal-hal fundamental dari nilai dan standar perilaku orang yang dinilai baik atau buruk dalam menjalankan profesinya yang secara mandiri dirumuskan, ditetapkan dan ditegakkan oleh organisasi profesi.
\end{abstract}

Kata Kunci: Peran Notaris, Pemahaman Hukum, Masyarakat Kurang Mampu, Akta Notariil

\section{A. PENDAHULUAN}

\section{Latar Belakang Masalah}

Pertumbuhan masyarakat yang berpengaruh dengan kehidupan sosial banyak menimbulkan peristiwa maupun perbuatan hukum. Dalam peristiwa maupun perbuatan hukum tersebut, tidak semua masyarakat berkaitan erat dengan tugas jabatan Notaris, tetapi hanya masyarakat yang berkepentingan/penghadap saja yang berkaitan dengan tugas Notaris misalnya masyarakat yang melakukan perjanjian jual beli tanah, walaupun dampaknya juga bisa berpengaruh terhadap masyarakat luas, namun yang berkaitan dengan asas pacta sunt servanda hanya untuk para pihak. Sebagai praktisi di bidang hukum, Notaris berkewajiban melayani masyarakat berdasarkan tugasnya yang telah diamanatkan oleh Undang-Undang untuk mendukung terciptanya kepastian, ketertiban dan perlindungan hukum bagi masyarakat.
Keberadaan Akta autentik sebagai alat bukti tertulis, mempunyai peranan penting dalam setiap hubungan hukum dalam kehidupan masyarakat, dalam berbagai kegiatan ekonomi, kegiatan di bidang perbankan, pertanahan, kegiatan sosial, dan lain-lain. Kebutuhan akan pembuktian tertulis berupa akta autentik makin meningkat sejalan dengan berkembangnya tuntutan akan kepastian hukum dalam berbagai hubungan ekonomi dan sosial, baik pada tingkat nasional, regional, maupun global. Dengan akta autentik dapat ditentukan secara jelas hak dan kewajiban, menjamin kepastian hukum dan sekaligus diharapkan pula dapat menghindari terjadinya sengketa.

Penyuluhan-penyuluhan hukum yang dilakukan oleh Notaris biasanya dilakukan kepada orang-orang yang tidak mampu. Tidak mampu di sini ada 2 (dua) makna, yaitu: tidak mampu dari aspek ekonomi dan tidak mampu dari aspek pengetahuan atau pemahaman. Orang kaya bisa dikatakan tidak mampu 
karena tidak punya pengetahuan atau pemahaman tentang akta Notaris.

Adapun maksud dari dilakukannya penyuluhan-penyuluhan hukum supaya menjadikan masyarakat paham akan hukum. Dalam arti memahami maksud dari ketentuan-ketentuan yang terkandung dalam peraturan-peraturan hukum yang mengatur kehidupannya sebagai warga negara yang baik, dan meningkatkan kesadaran hukum warga masyarakat sehingga setiap warga taat pada hukum dan secara ikhlas tanpa dorongan atau paksaan dari siapapun melaksanakan hak dan kewajibannya sebagaimana ditentukan oleh hukum yang berlaku.

Berdasarkan uraian tersebut di atas, maka penulis tertarik untuk melakukan penelitian lebih lanjut dengan judul "PERAN NOTARIS DALAM MEMBERIKAN PEMAHAMAN HUKUM KEPADA MASYARAKAT YANG KURANG MAMPU DALAM MEMAHAMI HUKUM KAITANNYA DALAM PEMBUATAN AKTA-AKTA NOTARIIL DI WILAYAH KEDU SELATAN".

\section{Rumusan Masalah}

Berdasarkan uraian pada latar belakang masalah tersebut di atas, maka permasalahan dalam penelitian ini dapat dirumuskan sebagai berikut:

a. Bagaimana pemahaman masyarakat terhadap akta notariil dan fungsinya?

b. Bagaimana peran Notaris dalam memberikan pemahaman hukum kepada masyarakat yang kurang mampu dalam memahami hukum kaitannya dalam pembuatan akta-akta notariil di wilayah Kedu Selatan?

c. Bagaimana peran Ikatan Notaris Indonesia (INI) dalam pembinaan terhadap Notaris untuk memberikan pemahaman hukum kepada masyarakat yang kurang mampu dalam memahami hukum kaitannya dengan pembuatan akta notariil?

\section{B. PEMBAHASAN}

\section{Pemahaman Masyarakat Terhadap Akta Notariil dan Fungsinya}

Dewasa ini masyarakat mulai menyadari arti pentingnya sebuah jaminan akan kepastian hukum terhadap perbuatan dan tindakan sehari-hari, sehingga banyak orang yang menuangkannya di dalam akta Notaris, baik itu yang berbentuk perikatan yang melibatkan pihak lain maupun sekedar untuk menyatakan maksud tertentu agar dijadikan sebagai dokumen legal yang mempunyai kekuatan hukum, dengan harapan untuk mendapatkan kepastian hukum dikemudian hari.

Berdasarkan hasil wawancara penulis dengan H. Agus Wahyu Nugroho, SH. M.Kn., selaku Notaris di Kabupaten Purworejo, ${ }^{1}$ diperoleh keterangan bahwa tugas Notaris adalah mendokumentasikan perbuatan hukum para penghadapnya kedalam bentuk akta Notaris yang bersifat autentik dan mempunyai kekuatan pembuktian yang sempurna secara yuridis. Notaris adalah pejabat umum yang diberikan kewenangan oleh undang - undang untuk membuat akta autentik. Notaris memiliki kewenangan dalam memberikan kepastian hukum kepada masyarakat khususnya dalam lingkup perdata yang terjadi karena perikatan.

Melalui akta yang dibuatnya, Notaris harus dapat memberikan kepastian hukum kepada masyarakat pengguna jasa Notaris. ${ }^{2}$ Akta Notaris adalah akta autentik yang memiliki kekuatan hukum dengan jaminan kepastian hukum sebagai alat bukti tulisan yang sempurna (volledig bewijs), tidak memerlukan tambahan alat pembuktian lain, dan hakim terikat karenanya. ${ }^{3}$

Akta yang dibuat oleh (door) Notaris dalam praktik Notaris disebut akta relaas atau akta berita acara yang berisi berupa uraian Notaris yang dilihat dan disaksikan Notaris sendiri atas permintaan para pihak, agar tindakan atau perbuatan para pihak yang dilakukan dituangkan kedalam bentuk akta Notaris. Akta yang dibuat dihadapan (ten overstaan) Notaris, dalam praktik Notaris disebut akta pihak, yang berisi uraian atau keterangan, pernyataan para pihak yang diberikan atau yang diceritakan dihadapan Notaris. Para pihak berkeinginan agar uraian atau keterangannya dituangkan kedalam bentuk akta Notaris. $^{4}$

\section{Peran Notaris Dalam Memberikan Pemahaman} Hukum Kepada Masyarakat Yang Kurang Mampu Dalam Memahami Hukum Kaitannya dalam Pembuatan Akta-Akta Notariil di Wilayah Kedu Selatan

Berkaitan dengan pemberian penyuluhan hukum oleh Notaris, telah diatur pula dalam Pasal 15 ayat (2) huruf e UUJN, bahwa Notaris berwenang memberikan penyuluhan hukum dan penjelasanpenjelasan kepada pihak-pihak yang berkepentingan

1 Wawancara dengan H. Agus Wahyu Nugroho, SH. M.Kn., selaku Notaris di Kabupaten Purworejo, pada tanggal 27 Februari 2017

2 H. Salim HS. dan H. Abdullah, 2007, Perancangan Kontrak dan MOU, Sinar Grafika, Jakarta, hal. 101102

3 A.A. Andi Prajitno, 2010, Apa dan Siapa Notaris di Indonesia?, Cetakan Pertama, Putra Media Nusantara, Surabaya, hal.51

4 Habib Adjie, 2008, Hukum Notaris Indonesia (Tafsir Tematik Terhadap UU No.30 Tahun 2004 Tentang Jabatan Notaris), PT. Refika Aditama, Bandung, hal. 128 
sehubungan dengan pembuatan akta yang akan, sedang dan/atau dibuat sampai sempurnanya akta. ${ }^{5}$

Berdasarkan hasil wawancara penulis dengan H. Agus Wahyu Nugroho, SH. M.Kn., selaku Notaris di Kabupaten Purworejo, ${ }^{6}$ diperoleh keterangan bahwa tujuan penyuluhan hukum agar masyarakat tahu hukum, paham hukum, sadar hukum, untuk kemudian patuh pada hukum tanpa paksaan, tetapi menjadikannya sebagai suatu kebutuhan. Pemahaman seseorang tentang hukum beranekaragam dan sangat tergantung pada apa yang diketahui dari pengalaman yang dialaminya tentang hukum.

Dalam memberikan penyuluhan hukum, Notaris berperan untuk selalu bertindak jujur dan tidak berpihak, memberikan pelayanan sesuai dengan ketentuan yang berlaku didalam undang-undang, serta merahasiakan segala keterangan dan segala sesuatu yang diperolehnya dari para penghadap atau kliennya kepada pihak lain.

\section{Peran Ikatan Notaris Indonesia (INI) dalam Pembinaan Terhadap Notaris Untuk Memberikan Pemahaman Hukum Kepada Masyarakat Yang Kurang Mampu dalam Memahami Hukum Kaitannya Dengan Pembuatan Akta Notariil}

Sering kita jumpai suatu organisasi profesi terdapat kode etiknya, hal ini dipandang sangat perlu untuk memberikan pedoman berprilaku bagi anggotanya. Jabatan yang diemban Notaris adalah suatu jabatan kepercayaan yang diberikan oleh undangundang dan masyarakat, maka dari itulah seorang Notaris bertanggung jawab untuk melaksanakan kepercayaan yang diberikan kepadanya dengan selalu menjunjung tinggi etika hukum dan martabat serta keluhuran jabatannya, sebab apabila hal tersebut diabaikan oleh seorang Notaris maka dapat menimbulkan kerugian bagi masyarakat serta nama baik Notaris itu sendiri.

Ikatan Notaris Indonesia (INI) merupakan satu-satunya Organisasi Notaris yang diatur dalam Undang-undang Nomor 30 tahun 2004 tentang Jabatan Notaris Pasal 82 dan 83, kemudian dirubah dalam Undang-undang Nomor 2 Tahun 2014 tentang Perubahan Undang-undang Jabatan Notaris Pasal I angka 41 berbunyi sebagai berikut:

(1) Notaris berhimpun dalam satu wadah Organisasi Notaris.

(2) Wadah Organisasi Notaris sebagaimana dimaksud pada ayat (1) adalah Ikatan Notaris Indonesia.

5 G.H.S. Lumban Tobing, 1983, Peraturan Jabatan Notaris, Erlangga, Jakarta, hal. 41

6 Wawancara dengan H. Agus Wahyu Nugroho, SH. M.Kn., selaku Notaris berkedudukan di Kabupaten Purworejo, pada tanggal 27 Februari 2017
(3) Organisasi Notaris sebagaimana dimaksud pada ayat (1) merupakan satusatunya wadah profesi Notaris yang bebas dan mandiri yang dibentuk dengan maksud dan tujuan untuk meningkatkan kualitas profesi Notaris.

(4) Ketentuan mengenai tujuan,tugas,wewenang,tata kerja dan susunan organisasi ditetapkan dalam Anggaran Dasar dan Anggaran Rumah Tangga Organisasi Notaris.

(5) Ketentuan mengenai penetapan, pembinaan dan pengawasan Organisasi Notaris di atur dengan Peraturan Menteri.

\section{PENUTUP}

\section{Kesimpulan}

1. Pemahaman masyarakat tentang akta notariil dan fungsinya belum memadai, sehingga banyak orang yang menuangkannya di dalam akta Notaris, baik itu yang berbentuk perikatan yang melibatkan pihak lain maupun sekedar untuk menyatakan maksud tertentu agar dijadikan sebagai dokumen legal yang mempunyai kekuatan hukum, dengan harapan untuk mendapatkan kepastian hukum dikemudian hari. Akan tetapi banyak masyarakat ataupun para penegak hukum dan bahkan para Notaris sendiripun masih banyak yang kurang memahami peranan tugas dan tanggung jawab Notaris dalam masyarakat terutama dalam membuat akta autentik. Notaris merupakan profesi mulia (officium nobile) hal ini dikarenakan profesi Notaris sangat erat hubungannya dengan kemanusiaan. Akta yang dibuat Notaris dapat menjadi alas hukum atas status harta benda, hak dan kewajiban bagi seseorang. Kekeliruan atas akta Notaris dapat menyebabkan hilangnya hak seseorang dan bahkan terbebaninya seseorang atas suatu kewajiban.

2. Peran Notaris dalam memberikan pemahaman hukum kepada masyarakat yang kurang mampu dalam memahami hukum kaitannya dalam pembuatan akta notariil dilakukan dengan penyuluhan hukum kepada kliennya, dapat dibagi menjadi 2 (dua) kriteria, yaitu penyuluhan hukum yang diikuti dengan pembuatan akta dan penyuluhan hukum tanpa diikuti dengan pembuatan akta. Penyuluhan hukum yang diikuti dengan pembuatan akta merupakan satu kesatuan yang tidak dapat dipisahkan.

3. Tugas Ikatan Notaris Indonesia (INI) dalam pembinaan Notaris tidak lepas dari pada penegakan Etika Notaris, meliputi norma agama, norma hukum, norma kesusilaan, dan norma kesopanan. Norma agama, norma kesusilaan, dan norma kesopanan berhubungan dengan etika. Kode Etik dalam arti materiil adalah norma atau 
peraturan yang praktis baik tertulis maupun tidak tertulis mengenai etika berkaitan dengan sikap serta pengambilan putusan hal-hal fundamental dari nilai dan standar perilaku orang yang dinilai baik atau buruk dalam menjalankan profesinya yang secara mandiri dirumuskan, ditetapkan dan ditegakkan oleh organisasi profesi.

\section{DAFTAR PUSTAKA}

A.A. Andi Prajitno, 2010, Apa dan Siapa Notaris di Indonesia?, Cetakan Pertama, Putra Media Nusantara, Surabaya

GHS Lumban Tobing, 2006, Peraturan Jabatan Notaris, Erlangga, Jakarta
H. Salim HS. dan H. Abdullah, 2007, Perancangan Kontrak dan MOU, Sinar Grafika, Jakarta

Habib Adjie, 2008, Hukum Notaris Indoensia Tafsir Tematik Terhadp UU NO. 30 Tahun 2004 tentang Jabatan Notaris, Rafika Aditama, Bandung

Undang-Undang Nomor 2 Tahun 2014 tentang Perubahan atas Undang-Undang Nomor 30 Tahun 2004 tentang Jabatan Notaris

Wawancara dengan H. AGUS Wahyu Nugroho, SH. M.Kn Notaris berkedudukan di Kabupaten Purworejo, pada hari Senin tanggal 27 Februari 2017 